\title{
Novela stavebního zákona v praxi a její dopad na povolování staveb
}

\section{Amendment to the Building Act in Practice and its Impact on Construction Permitting}

\author{
Alena Kliková* \\ Masarykova univerzita, Právnická fakulta
}

\begin{abstract}
Abstrakt
Př́íspěvek je věnován otázkám spojeným se změnami a legislativním vývojem právní úpravy stavebního zákona, a to ve vztahu k praktickým dopadům těchto změn. Stavební zákon v posledních letech neustále prochází změnami, které mají vést ke zrychlení a zjednodušení jednotlivých procesů vedoucích k povolování staveb. Dne 1. 1. 2018 nabyla účinnosti další velká novela stavebního zákona, která měla opět vést ke zjednodušení a zrychlení procesů povolování staveb. Př́spěvek bude zaměřen na vybrané praktické problémy při povolování staveb v návaznosti na změny, které zmiňovaná novela přinesla. Př́spěvek byl prezentován na konferenci ExFoS 2019 ve dnech 24.-25. ledna 2019.
\end{abstract}

Klíčová slova: stavební zákon, územní plánování, stavební povolení, kolaudace, užívání staveb.

\section{1. ÚVOD}

Již od nabytí účinnosti „nového“ stavebního zákona ${ }^{1)}$ v roce 2017 odborná i laická veřejnost opakovaně diskutuje o nutnosti novelizovat tento zákon, popr. schválit nový. Stavební zákon byl již mnohokrát novelizován. Řada z těchto novel byla tzv. zásadní (bývají označovány jako velké novely). Poslední velká novela byla schválena v roce 2017 (zákon č. 225/2017 Sb.) s účinností od 1. 1. 2018. Avšak ani tato legislativní změna nepřinesla očekávané výsledky a nedosáhla kýženého cíle. Bohužel došlo ke zvýšení průtahů v povolovacích procesech. Aby bylo možné některé problémy odstranit, byla schválena další novela č. 169/2018 Sb. (s účinností od 1. 9. 2018). Ani přes tuto dílčí legislativní úpravu nebyly odstraněny vytýkané vady zákona a navazujících novelizací. I nadále se vedou diskuze o nutnosti velké rekodifikaci celého

1) Zákon č. 183/2006 Sb.

\begin{abstract}
The paper deals with the issues related to the changes and the legislative development of the legal regulation of the Building Act, in relation to the practical effects of these changes. The Building Act has been constantly undergoing changes in recent years to lead to the acceleration and simplification of individual construction permitting processes. On 1 January 2018, another major amendment to the Building Act came into force, which should once again lead to the simplification and acceleration of construction permitting processes. The paper will focus on selected practical problems in permitting in relation to the changes brought by the amendment. The paper was presented at the ExFoS 2019 conference, 24-25 ${ }^{\text {th }}$ January.
\end{abstract}

Keywords: building act, territorial planning, building permits, acceptance, use of buildings.

veřejného stavebního práva. Jeden z návrhů, který byl zveřejněn v prosinci 2018, je návrh Hospodářské komory. Jak je uvedeno v návrhu předkladatel (Hospodářská komora) má za cíl přiblížit veřejné stavební právo standardům vedoucím $\mathrm{k}$ jeho zefektivnění, odstranění obstrukcí, průtahů či bariér, které dnes omezují výstavbu a rozvoj České republiky. Jde o dosažení spravedlivé rovnováhy mezi všemi zájmy, jež se ve stavebním právu v širším smyslu projevují. Dnešní společenské a ekonomické prostředí si žádá, aby stavební právo stanovilo jednoduchá, aplikovatelná, vymahatelná a srozumitelná pravidla, která zajistí výstavbu klíčových dopravních staveb a další infrastruktury, např. dálnice, jiné pozemní komunikace, ropovody, přehrady (zejména $\mathrm{v}$ době problémů se suchem) aj.

Po novele stavebního zákona z roku 2017 došlo v řadě případů k prodloužení procesů povolování staveb, nebot' na stavebníky i stavební úřady jsou kladeny nové nároky, a to nejenom v navýšení podkladových stanovisek, ale i v návaznosti na nově nastavené 
procesy a postupy, které mohou činit komplikace. Povolování staveb je v České republice jedno z nejpomalejších na světě. Jde nejen o převažující závěry odborníků na české stavební právo a dotčených osob ze stavební branže. Tyto závěry plynou i z celosvětových srovnávacích dat, které publikuje Světová banka ve studiích Doing Business. Podle délky standardizovaného stavebního rrízení se Česká republika umístila na 156. místě ze 190 posuzovaných zemí s délkou 246 dnů.

Kritiky se novela stavebního zákona dočkala i ze strany Evropské komise, která ve Zprávě o České republice 2018 poukazuje na pochybnosti o prínosnosti novely pro nové stavební projekty. Zejména $\mathrm{v}$ té souvislosti zdůrazňuje chybějící zahrnutí různých jiných povolení do spojeného územního a stavebního řízení. Zmiňuje, že pro velké projekty v oblasti infrastruktury tento zjednodušený postup nebude fungovat. Kromě toho ve své zprávě mezi nedostatky nové úpravy zahrnuje skutečnost, že neexistuje povinnost územní a stavební řízení spojit. Současně Evropská komise vyjadřuje obavu, že novela omezuje stávající práva občanské společnosti podílet se na různých fázích projektu. Proto ve zprávě shrnuje, že tato novela prostor pro zjednodušení plně nevyužila.

Příspěvek se níže bude věnovat konkrétním problematickým bodům předmětné novely a jejich dopadu do praxe.

\section{VYBRANÉ PROBLÉMY}

\subsection{Orgán územního plánování jako dotčený orgán}

Jedním z nejvíce kritizovaných se stal nový § 96b, který zakotvil novou pravomoc orgánu územního plánování, a to jeho postavení jako dotčeného orgánu. Důvodová zpráva k novele uváděla, že se jedná o stěžejní ustanovení, bez kterého by novela řádně nefungovala. Závazné stanovisko orgánu územního plánování mělo koordinovat využití území a plnit další cíle a úkoly územního plánování. Dále uváděla důvodová zpráva, že novela stavebního zákona ve značné míře omezila vydávání samostatných územních rozhodnutí, místo nichž mělo být vydáváno závazné stanovisko do společného rozhodnutí. Čímž mělo dojít ke snížení administrativy ve vztahu ke stavebníkovi ${ }^{2}$. Bohužel se tento předpoklad nenaplnil. Ustanovení §96b stavebního zákona bylo vykládáno různými způsoby. Zavedení tohoto institutu do praxe bylo (a je) velmi komplikované. Řada orgánů územního plánování nebyla připravena personálně na obrovské navýšení agendy a tak lhůty pro vydávání předmětných závazných stanovisek jsou velmi dlouhé. Městský úřad Říčany na svých webových stránkách dne 29. 6. 2018 např. uvádí: „Za první pololetí roku 2018 obdržel zdejší úrúad územního plánování něco prèes 1000 žádostí, z nichž zvládl s maximálním nasazením pracovníkủ vyř́dit přibližně 40 \%". Dále jak uváděla média nap̌r. v Černošicích, pod něž patří přes 70 obcí, si stavebník počká možná až rok ${ }^{3}$. V lednu 2018 vydalo Ministerstvo pro místní rozvoj rozsáhlou metodiku ${ }^{4}$, která měla přinést očekávané vysvětlení a sjednocení postupů. Bohužel i přes rozsáhlost této metodiky (158 stran) ke zrychlení jednotlivých

2) Důvodová zpráva k zákonu č. 225/2017 Sb., zdroj: ASPI

3) Zdroj: https://www.idnes.cz/ekonomika/domaci/stavebni-povoleni-ceskourady.A180319_390081_ekonomika_elka (dne 6.1.2018)

4) Závazná stanoviska orgánů územního plánování - Př́iklady s komentářem, zdroj: www.mmr.cz postupů nedošlo. V dubnu vydalo Ministerstvo pro místní rozvoj další metodiku „Metodické sdělení Ministerstva pro místní rozvoj, kdy se nevydává závazné stanovisko orgánu územního plánování“ a v červenci 2018 bylo vydáno další „Závazná stanoviska orgánů územního plánování, Metodický pokyn 2. vydání“.

Z výše uvedených důvodů došlo k novele předmětného ustanovení, a to zákonem č. 169/2018 Sb., kterým se mění zákon č. 416/2009 Sb., o urychlení výstavby dopravní, vodní a energetické infrastruktury a infrastruktury elektronických komunikací, ve znění pozdějších předpisů, a další související zákony. Ministerstvo pro místní rozvoj následně přistoupilo $\mathrm{k}$ vydání další metodické pomůcky „Závazná stanoviska orgánů územního plánování Metodický pokyn 3. vydání“.5)

Je otázkou, zda poslední novela přispěje ke snížení časové a administrativní zátěže. $Z$ dosavadní praxe se však zdá, že pouze v omezené míre.

Problém v první řadě vyvolává otázka, zda je nutné žádat o závazné stanovisko vždy ke všem stavebním záměrům. Jak uvádí zákon, závazné stanovisko je nutné získat pro umíst'ování staveb, změnu užívání a dodatečné povolení, jestliže to závisí na posouzení vyvolané změny v území. Závazné stanovisko se nevydává pro stavby vyjmenované v ustanovení §96b odst. 1 stavebního zákona ${ }^{6)}$.

Sporným je dále otázka, kdo má o závazné stanovisko žádat. Stavební zákon sice nastavuje zákonné pravidlo, ale protože řada stavebníků není odborníkem na danou oblast, předmětné ustanovení tak nechápou a v praxi vznikají další problémy. Stavební zákon uvádí: „Pokud je stavební úr̆ad zároveň orgánem územního plánováni př́slušným $k$ vydání závazného stanoviska, obstarává závazné stanovisko orgánu územního plánováni stavební úr̆ad, není-li toto závazné stanovisko součástí koordinovaného závazného stanoviska. “7) V případě, že se jedná o tento případ, avšak žádost o vydání závazného stanoviska podá stavebník, dochází k různým přístupům ze strany orgánu územního plánování. Nepopiratelný je fakt, že text zákona jasně uvádí, že v tomto případě má o závazné stanovisko požádat (obstarat) sám stavební úruad a pouze $\mathrm{v}$ př́padě, kdy orgán územního plánování není stavebním úřadem, si má závazné stanovisko obstarat sám stavebník.

5) https:/www.mmr.cz/cs/Ministerstvo/Stavebni-pravo/Stanoviska-ametodiky/Stanoviska-odboru-uzemniho-planovani-MMR/5-Organyuzemniho-planovani,-dotcene-organy/Zavazna-stanoviska-organuuzemniho-planovani-Met.

6) Závazné stanovisko orgánu územního plánování se nevydává pro:

a) záměry uvedené $v \S 79$ odst. 2,

b) záměry uvedené $\mathrm{v} \S 80$ odst. 3 ,

c) záměry uvedené v $\S 103$ odst. 1 písm. c) až e), které nezasahují do nezastavěného území,

d) dělení a scelování pozemků v nezastavěném území, nejedná-li se o pozemkové úpravy,

e) studny individuálního zásobování vodou,

f) stavby nebo zařízení na zastavěných stavebních pozemcích rodinných domů související s bydlením či bydlení podmiňující a terénní úpravy potřebné k řádnému a bezpečnému uživání těchto pozemků, staveb a zařízení na nich,

g) stavby pro podnikatelskou činnost do $25 \mathrm{~m} 2$ zastavěné plochy a do $5 \mathrm{~m}$ výšky s jedním nadzemním podlažím, podsklepené nejvýše do hloubky $3 \mathrm{~m}$ na zastavěných stavebních pozemcích rodinných domů,

h) stavby nebo zařízení na zastavěných stavebních pozemcích staveb pro rodinnou rekreaci související s rodinnou rekreací či rodinnou rekreaci podmiňující a terénní úpravy potřebné $\mathrm{k}$ řádnému a bezpečnému užívání těchto pozemků, staveb a zařízení na nich.

7) Ustanovení $§ 96 b$ odst. 2 stavebního zákona. 
Povolování staveb vodních děl ve společném územním a stavebním řízení a povolování nakládání s vodami

Ve společném územním a stavebním řízení dle stavebního zákona je možné s účinností od 1.1.2018 povolovat nejenom stavby obecné, ale i vybrané stavby speciální. ${ }^{8), 9)}$ Jako další problematický bod novely stavebního zákona můžeme označit vydávání společného povolení pro stavby vodních děl. I když se nejedná o absolutní novinku, lze konstatovat, že některé postupy ve společném řízení budou minimálně komplikované a časově náročné. Za nejproblematičtější bod je označována otázka povolováni nakládání s vodami ve vztahu $\mathrm{k}$ povolování staveb vodních děl ve společném řízení. Správním orgánem povolujícím nakládání $\mathrm{S}$ vodami je dle vodního zákona ${ }^{10)}$ vodoprávní úráad. Dle ustanovení $\S 9$ odst. 5 vodního zákona věta první „Povoleni $k$ nakládáni s vodami, které lze vykonávat pouze uživáním vodního dila, je možné vydat jen současně se stavebním povolením k takovému vodnímu dilu ve společném řizení, pokud se nejedná o vodní dilo již existujíci nebo povolené, nebo které bude povolovat ve společném územním a stavebnim řizení podle zvláštního zákona jiný správní orgán než vodoprávní úřad." Vzhledem k tomu, že povolování souborů staveb ve společném územním a stavebním řízení se týká mimo jiné i staveb vodních děl, která vyžadují povolení k nakládání s vodami, a stavebním úřadem povolujícím stavby ve společném řízení nemusí být vždy vodoprávní úřad, je otázka vydávání povolení k nakládání s vodami velmi aktuální.

Ve společném řízení o povolení souboru staveb v případě, kdy je soubor staveb tvořen jak obecnými, tak speciálními stavbami, může nastat situace, že př́islušným k vydání společného povolení nebude vodoprávní úrúad ${ }^{11)}$, je tedy nutné, aby bylo vydáno povolení $\mathrm{k}$ nakládání $\mathrm{s}$ vodami vodoprávním úřadem samostatně jako podkladové rozhodnutí. Až po nabytí právní moci takovéhoto podkladového rozhodnutí bude možné pokračovat ve společném řízení o povolení souboru staveb. Je otázkou, zda $\mathrm{v}$ těchto př́ípadech skutečně dojde $\mathrm{k}$ časové úspoře pro stavebníka v povolovacím procesu.

Pro dokreslení složitosti dané situace je vhodné ještě doplnit, že vodoprávní úřad bude ve společném územním a stavebním řízení ještě v postavení dotčeného orgánu dle ustanovení §94j odst. 2 věta druhá stavebního zákona, který stanoví, že „Stavební úr̆ady př́slušné k umisténi nebo povolení vedlejšich staveb souboru jsou ve společném územním a stavebním řizení dotčenými orgány a pro potřeby vydání společného povolení vydávají namisto rozhodnuti závazná stanoviska. " Vodoprávní úřad bude v předmětném společném územním a stavebním řízení vystupovat $\mathrm{v}$ několika pozicích, a to jako orgán vydávající podkladové rozhodnutí ve vodoprávním řízení, dále jako dotčený orgán vydávající závazné stanovisko na místo povolení stavby vodního díla, které je součástí souboru staveb a dále jako dotčený orgán chránící veřejné zájmy, jejichž ochrana je mu svěřena vodním zákonem dle ustanovení § 104 odst. 9 vodního zákona. V této souvislosti stojí za zmínku, že ve vybraných situacích bude vodoprávní úřad ještě vydávat souhlas dle ustanovení $\S 17$ vodního zákona. V některých případech ${ }^{12)}$ $\mathrm{k}$ tomu bude ještě přistupovat rozhodnutí vodoprávního úřadu o schválení manipulačního řádu. ${ }^{13)}$

Opakem výše zmíněné situace bude stav, kdy orgánem povolujícím soubor staveb bude vodoprávní úřad. O povolení $\mathrm{k}$ nakládání s vodami bude vodoprávní úřad rozhodovat $\mathrm{v}$ rámci společného územního a stavebního řízení, $v$ němž bude zároveň ${ }^{14)}$ rozhodovat o nakládání s vodami. Vodoprávní úruad v rámci jednoho společného řízení, tak bude rozhodovat o povolení umístění souboru staveb, o povolení realizace jednotlivých staveb ze souboru staveb ${ }^{15}$, dále o povolení k nakládání s vodami na vodním díle, které je součástí souboru staveb. Jak bylo uvedeno výše, může vzniknout i situace, kdy bude nutné zároveň schvalovat i manipulační řád.

\section{ZÁVĚR}

Jak je $\mathrm{z}$ výše uvedeného patrné, $\mathrm{v}$ mnoha případech nedošlo novelou ke zjednodušení a zrychlení povolovacích procesů. V řadě př́ípadů je situace spíše opačná a časová náročnost získání povolení stavby je výrazně větší, než tomu bylo před novelou. Z materiálu předloženého na jednání vlády dne 5. 9. 2018 vyplývá, že i Ministerstvo pro místní rozvoj si je dané situace vědomo a připravuje rekodifikaci veřejného stavebního práva. ${ }^{16)}$ Vzhledem $\mathrm{k}$ rozsáhlosti řešené problematiky a ke stávajícímu legislativnímu stavu, je cesta k vyřešení ještě dlouhá. Dle harmonogramu rekodifikace veřejného stavebního práva Ministerstva pro místní rozvoj se předpokládá schválení věcného záměru nového stavebního zákona v první čtvrtletí 2020. Schválení samotného zákona je předpokládáno na rok 2022.
8) Ustanovení § 94j odst. 1 stavebního zákona „U staveb v působnosti obecného stavebního úřadu, staveb vymezených v $\$ 15$ odst. 1 písm. b) až d) a staveb vymezených v $§ 16$ odst. 2 písm. d) lze vydat společné povolení. Příslušným k vydání společného povolení je stavební úřad př́slušný k povolení stavby podle $\S 13$ odst. $1, \S 15$ odst. 1 písm. b) až d) nebo $\S 16$ odst. 2 písm. d).“

9) Konkrétně se jedná o stavby drah, stavby dálnic, silnic, místních komunikací a veřejně př́stupných komunikací a stavby vodních děl. Dále se jedná o stavby k účelům těžby, zpracování, transportu a ukládání radioaktivních surovin na území vyhrazeném pro tyto účely, u staveb souvisejících s úložišti radioaktivních odpadů obsahujících výlučně přírodní radionuklidy a u staveb v areálu jaderného zařízení, u staveb ropovodů a produktovodů a u staveb zařízení pro přenos elektrriny, zařízení pro přepravu plynu, zařízení pro uskladňování plynu nebo výrobny elektřiny o celkovém instalovaném elektrickém výkonu $100 \mathrm{MW}$ a víc.

10) Zákon č. 254/2001 Sb., ve znění pozdějších předpisů.

11) Ustanovení $\S 94 j$ odst. 2 věta první stavebního zákona „U souboru staveb se příslušnost $\mathrm{k}$ vydání společného povolení řídí příslušností $\mathrm{k}$ povolen stavby hlavní souboru staveb.“
12) Ustanovení $\S 15$ odst. 7 „Vodoprávní úrad může vyzvat žadatele o stavební povolení $\mathrm{k}$ předložení návrhu manipulačního řádu, popř́padě výpočtu povodňové vlny zvláštní povodně, a to u vodních děl vzdouvajících nebo akumulujících povrchové vody a staveb využívajících jejich energetický potenciál."

13) Ustanovení $§ 115$ odst. 18 vodního zákona „Manipulační řád vodního díla schvaluje vodoprávní úřad rozhodnutím.“

14) Pozn. týká se to povolení k nakládání s vodami, které lze vykonávat pouze užíváním vodního díla (viz. ustanovení $§ 9$ odst. 5 vodního zákona).

15) Dle ustanovení $\$ 94$ p by o umístění a povolení realizace mělo být rozhodnuto v rámci jednoho výroku rozhodnutí, a to tak, že záměr je schválen.

16) https://www.mmr.cz/getmedia/d4cc64b7-8a88-4130-a3f9-e391c7bb2db0/ Rekodifikace_info_vlada_30-8-2018_1.pdf.aspx?ext=.pdf (dne 6.1.2019). 


\section{LITERATURA}

[1] Stavební zákon č. 183/2006 Sb., ve znění pozdějších předpisů.

[2] Důvodová zpráva k zákonu č. 225/2017 Sb.

[3] Návrh rekodifikace veřejného stavebního práva.

[4] KLIKOVÁ, A. Novela stavebního zákona v praxi a její dopad na povolování staveb. In Sborník přispěvkỉ konference Expert Forensic Science Brno 2019. VUT v Brně, 2019, s. 329-334. ISBN 978-80-214-5708-9.

\section{Správná citace:}

KLIKOVÁ, A. Novela stavebního zákona v praxi a její dopad na povolování staveb. Soudní inženýrství, 2019, 30(3), 42-45. DOI: http:// dx.doi.org./10.13164/SI.2019.3.42. ISSN 1211-443X. 